\title{
EFFECT OF ACETYLCHOLINE, PILOCARPINE, SEROTONIN AND ADRENALINE ON THE IN VITRO GASTRIC MOTILITY OF Hoplias malabaricus (TELEOSTEI)
}

\author{
Vânia L. Pimentel Vieira, Bernardo Baldisserotto and Sílvia Krause \\ Departamento de Fisiologia - CCS \\ UFSM - Santa Maria, RS
}

\section{RESUMO}

O efeito da acetilcolina, pilocarpina, serotonina e adrenalina na motilidade gástrica "in vitro" do teleósteo Hoplias malabaricus foi analisado. O estômago desta espécie apresenta uma atividade contrátil espontânea. Não se detectou nenhuma relação entre tensão ou frequência das contrações estomacais com o peso total dos peixes. A acetilcolina diminuiu a frequência das contrações nas concentrações $5 \times 10^{-8} \mathrm{M}$ e $10^{-7} \mathrm{M}$ e aumentou a tensão e o tônus das contrações estomacais nestas mesmas concentrações. A pilocarpina aumentou a frequência das contrações estomacais nas concentrações $10^{-8} \mathrm{M}, 5 \times 10^{-8} \mathrm{M}$ e $10^{-7} \mathrm{M}$, aumentou a tensão nas concentrações $5 \times 10^{-8} \mathrm{M} \mathrm{e} 10^{-7} \mathrm{M}$ e o tônus na concentração $10^{-7}$ M. A serotonina e a adrenalina não alteraram a frequência, tensão e tônus das contrações estomacais em nenhuma das concentrações utilizadas. Encontrou-se uma correlação significativa entre as doses de acetilcolina e pilocarpina e a tensão das contrações. Os resultados com acetilcolina e pilocarpina permitem concluir que o estômago de $H$. malabaricus possui receptores colinérgicos muscarínicos. Os resultados obtidos com adrenalina e serotonina não permitem demonstrar a existência de receptores adrenérgicos e serotoninérgicos no estômago desta espécie. 


\begin{abstract}
The in vitro effect of acetylcholine, pilocarpine, serotonin and adrenaline on gastric motility of the teleost Hoplias malabaricus was studied. The stomach of this species has spontaneous contractile activity, with no relationship between tension or frequency of contractions and fish weight. Acetylcholine reduced the frequency of contractions at higher concentrations, but had not effect at lower concentrations. The higher doses of this drug increased the tension and tonus of the contractions. Pilocarpine increased the frequency and tension of contractions at higher concentrations, but had not effect at lower concentrations, and increased tonus only at the concentration of $10^{-7} \mathrm{M}$. A significant correlation between the doses of acetylcholine and pilocarpine and tension of gastric contractions was found. Adrenaline and serotonin had not effect on the frequency, tension and tonus of the stomach contractions. The results obtained with acetylcholine and pilocarpine demonstrate that the stomach of $H$. malabaricus has muscarinic cholinoceptors. The results obtained with adrenaline and serotonin did not demonstrate the existence of adrenergic or serotonergic receptors in the stomach of this species.
\end{abstract}

\title{
INTRODUCTION
}

The stomach of fish varies in size and shape, but can be considered as an organ for short-term storage, mixing and primary digestion of food. In most carnivorous species such as Hoplias malabaricus, the stomach is generally more sac-or bag-like. A common feature of the stomachs of predatory fish is that they have highly elastic muscular walls which can expand to hold relatively large amounts of food (Jobling, 1995).

The extrinsic control of the fish gut by nerve fibers occurs in the vagi and in splanchnic nerves. Adrenergic neurons innervating the gut are of spinal autonomic origin. Stimulation of these nerves causes excitation of gut smooth muscle in some species, and an inhibition or mixed effects in other 
species, partly due to an effect of the transmitter on different subtypes of adrenergic receptors ( $\alpha$ and. $\beta$ adrenoceptors) (Nilsson, 1983). Similarly, stimulation of the vagal innervation of the gut has different effects on different species. When present, the excitatory effect can be attributed to stimulation of cholinergic nerves, while the nature of the inibitory vagal neurons present in some species still remains to be elucidated (Nilsson and Holmgren, 1993).

A number of reports are available on the effects of putative neurotransmitters in several elasmobranch and teleost fish species (Nilsson and Holmgren, 1993). In general, bombesin, gastrin/CCK and trachynins have an excitatory effect on gut smooth muscle, but exceptions occur. The same transmitter may have different effects on stomach and intestine. This is the case for the bombesin-related peptide, litorin, which is excitatory on stomach preparations, but inhibitory on the intestine of the cod Gadus morhua (Holmgren and Jönson, 1988). Few reports dealing with interactions between neurotransmitters in fish, are available, but potentiation of the response to acetylcholine caused by bombesin in the gut of the rainbow trout and cod has been observed (Thorndyke and Holmgren, 1990).

The involvement of cholinergic, adrenergic and serotonergic mechanisms in the motility of the gastrointestinal tract of fishes has been investigated by various authors (Burnstock, 1958a; Nilsson and Fänge, 1969; Edwards, 1972; Holmgren and Nilsson, 1974; Grove and Campbell, 1979; Holmgren, 1983; Holmgren and Nilsson, 1991; Jensen and Holmgren, 1985; Jensen and Holmgren, 1993). Acetylcholine and serotonin activate the contraction of intestinal smooth muscle of teleosts, while alpha and beta adrenergic agonists inhibit it (Fänge and Grove, 1979; Nilsson, 1983). In catfish intestine, serotonin also produced contractile responses in a dosedependent manner (Venugopalan, et al., 1995). However, adrenaline and noradrenaline provoked contractions and a strong rhythmic activity in the stomach of Gadus morhua, (Nilsson and Fänge, 1969).

The motility of the stomach of the freshwater teleost Hoplias malabaricus was analyzed with respect to variation in luminal $\mathrm{pH}$ 
(Baldisserotto et al, 1990), and the relationship between its anatomy and histology and its feeding habit was described by Menin (1988). Since the effect of drugs on the gastric motility of fishes changes from species to species, as seen above, the aim of this study was to investigate the effect of acetylcholine, pilocarpine, serotonin and adrenaline on the in vitro gastric motility of the teleost $H$. malabaricus.

\section{MATERIAL AND METHODS}

Specimens of Hoplias malabaricus (ERYTHRINIDAE) were caught with nets placed in ponds on the campus of the Universidade Federal de Santa Maria (UFSM), Santa Maria, Southern Brazil. Specimens were fasted for 3 days (Baldisserotto et al., 1990), and killed by section of the spinal cord. The cardic portion of the stomachs (according to the description of Menin, 1988) was removed and suspended in an organ bath (100 ml) containing aerated physiological solution $(\mathrm{mM})$ : $120.0 \mathrm{NaCl} ; 3.0 \mathrm{CaCl}_{2} ; 5.5$ $\mathrm{KCl} ; 1.45 \mathrm{MgSO}_{4} .7 \mathrm{H}_{2} \mathrm{O} ; 10.0 \quad \mathrm{NaHCO}_{3} ; 2.5 \quad \mathrm{C}_{6} \mathrm{H}_{12} \mathrm{O}_{6} ;$ (Mimura and Baldisserotto, 1988), adjusted to $\mathrm{pH} 7.0$ with $10 \mathrm{M} \mathrm{HCl}$ and maintained at $22^{\circ} \mathrm{C}$. Each stomach was connected to a force displacement transducer coupled to an ink-writing Ugo Basile physiograph to record the isotonic contractions. Gastric contractions were recorded in stomachs filled with a volume of physiological solution barely sufficient to distend their walls. Drugs were added to the bath in cumulative doses, and the effect of each dose was recorded for $10 \mathrm{~min}$. The following drugs were used: acetylcholine, pilocarpine, serotonin (Sigma) and adrenaline (Geyer).

Values are expressed as mean \pm SEM. Data about the effects of drugs on the frequency, tonus and tension of the stomach were compared to control values by one-way ANOVA and Duncan test using the SPSS program. The Slide Write Plus program (Advanced Graphics Software, Inc.) was used to construct the curve fitting the graph. The minimum significant level was $\mathrm{P}<0.05$. 
(Baldisserotto et al, 1990), and the relationship between its anatomy and histology and its feeding habit was described by Menin (1988). Since the effect of drugs on the gastric motility of fishes changes from species to species, as seen above, the aim of this study was to investigate the effect of acetylcholine, pilocarpine, serotonin and adrenaline on the in vitro gastric motility of the teleost $H$. malabaricus.

\section{MATERIAL AND METHODS}

Specimens of Hoplias malabaricus (ERYTHRINIDAE) were caught with nets placed in ponds on the campus of the Universidade Federal de Santa Maria (UFSM), Santa Maria, Southern Brazil. Specimens were fasted for 3 days (Baldisserotto et al., 1990), and killed by section of the spinal cord. The cardic portion of the stomachs (according to the description of Menin, 1988) was removed and suspended in an organ bath (100 ml) containing aerated physiological solution $(\mathrm{mM})$ : $120.0 \mathrm{NaCl} ; 3.0 \mathrm{CaCl}_{2} ; 5.5$ $\mathrm{KCl} ; 1.45 \mathrm{MgSO}_{4} .7 \mathrm{H}_{2} \mathrm{O} ; 10.0 \quad \mathrm{NaHCO}_{3} ; 2.5 \mathrm{C}_{6} \mathrm{H}_{12} \mathrm{O}_{6}$; (Mimura and Baldisserotto, 1988), adjusted to $\mathrm{pH} 7.0$ with $10 \mathrm{M} \mathrm{HCl}$ and maintained at $22^{\circ} \mathrm{C}$. Each stomach was connected to a force displacement transducer coupled to an ink-writing Ugo Basile physiograph to record the isotonic contractions. Gastric contractions were recorded in stomachs filled with a volume of physiological solution barely sufficient to distend their walls. Drugs were added to the bath in cumulative doses, and the effect of each dose was recorded for $10 \mathrm{~min}$. The following drugs were used: acetylcholine, pilocarpine, serotonin (Sigma) and adrenaline (Geyer).

Values are expressed as mean \pm SEM. Data about the effects of drugs on the frequency, tonus and tension of the stomach were compared to control values by one-way ANOVA and Duncan test using the SPSS program. The Slide Write Plus program (Advanced Graphics Software, Inc.) was used to construct the curve fitting the graph. The minimum significant level was $\mathrm{P}<0.05$. 


\section{RESULTS}

Even in the absence of drugs, a spontaneous contractile activity was observed in the stomach. Control tension varied from 0.5 to $3.1 \mathrm{~g}$, and frequency from 3 to 23 contractions in $10 \mathrm{~min}$. There was no relationship between tension or frequency of stomach contractions and fish weight (data not shown).

Acetylcholine reduced the frequency of contractions at concentrations of $5 \times 10^{-8} \mathrm{M}$ and $10^{-7} \mathrm{M}$, but had not effect at $10^{-9} \mathrm{M}, 5 \times 10^{-9} \mathrm{M}$ and $10^{-8} \mathrm{M}$ (Table 1). Acetylcholine concentrations of $5 \times 10^{-8} \mathrm{M}$ and $10^{-7} \mathrm{M}$ increased the tension and tonus of the gastric contractions (table 2). A correlation between the doses of acetylcholine, and pilocarpine and tension of gastric contractions was found (Figures 1 and 2). Pilocarpine increased the frequency of contractions at concentrations of $10^{-8} \mathrm{M}, 5 \times 10^{-8} \mathrm{M}$ and $10^{-7} \mathrm{M}$ (Table 1 ), the tension at concentrations of $5 \times 10^{-8} \mathrm{M}$ and $10^{-7} \mathrm{M}$, but only the concentration of $10^{-7} \mathrm{M}$ increased the tonus (table 2). Adrenaline and serotonin did not increase the frequency, tension or tonus of contractions in the stomach of $H$. malabaricus.

\section{DISCUSSION}

H. malabaricus is a moderately voracius carnivorous species with sedentary habits when in the adult stage (Azevedo and Gomes, 1943). The stomach of this species presents two layers of smooth muscle: an internal layer of circular muscle and a thinner external layer of longitudinal muscle. The gastric mucosa is folded into crypts and consists of three regions: cardic (easily distended), cecal (fundic) and pyloric (less distensible) (Menin, 1988). 
Table 1 - Effect of acetylcholine (Ach), pilocarpine (Pil), adrenaline (Adr) and serotonin $(5-\mathrm{Ht})$ on the frequency of contractions (in $10 \mathrm{~min}$ ) of the stomach of Hoplias malabaricus. Number of experiments (7).

Different from control values * $P<0.05$ (Duncan).

\begin{tabular}{|l|l|l|l|l|l|l|}
\hline & & & Doses $(\mathrm{M})$ & & & \\
\hline Drug & control & $10^{-9}$ & $5 \times 10^{-9}$ & $10^{-8}$ & $5 \times 10^{-8}$ & $10^{-7}$ \\
\hline Ach & $17.0 \pm 1.63$ & $15.4 \pm 1.04$ & $15.3 \pm 0.64$ & $14.2 \pm 0.59$ & $12.1 \pm .15^{\star}$ & $10.9 \pm 0.87^{*}$ \\
\hline Pil & $4.7 \pm 0.47$ & $5.0 \pm 0.58$ & $6.6 \pm 0.80$ & $7.7 \pm 1.06^{*}$ & $9.5 \pm 1.12^{*}$ & $10.8 \pm 0.26^{*}$ \\
\hline Adr & $21.4 \pm .1 .12$ & $18.8 \pm 1.43$ & $18.6 \pm 1.63$ & $19.8 \pm 1.77$ & $14.8 \pm 2.93$ & $15.6 \pm 3.59$ \\
\hline $5-\mathrm{Ht}$ & $14.1 \pm 1.75$ & $13.7 \pm 1.52$ & $13.8 \pm 1.37$ & $14.0 \pm 0.75$ & $13.5 \pm 1.01$ & $12.7 \pm 0.90$ \\
\hline
\end{tabular}

Table 2 - Effect of acetylcholine (Ach) and pilocarpine (Pil) on the tônus of contractions (in $10 \mathrm{~min}$ ) of the stomach of Hoplias malabaricus. Number of experiments (7).

Different from control values ${ }^{*} P<0.05$ (Duncan).

\begin{tabular}{|c|c|c|c|c|c|c|}
\hline & & & Doses (M) & & & \\
\hline Drug & Control & $10^{-9}$ & $5 \times 10^{-9}$ & $10^{-8}$ & $5 \times 10^{-8}$ & $10^{-7}$ \\
\hline Ach & $0.29 \pm 0.51$ & $0.51 \pm 0.18$ & $1.09 \pm 0.40$ & $1.51 \pm 0.52$ & $2.82 \pm 0.77$ & $3.30 \pm 0.84$ \\
\hline Pil & $0.29 \pm 0.05$ & $0.22 \pm 0.08$ & $0.26 \pm 0.14$ & $0.37 \pm 0.13$ & $0.62 \pm 0.11$ & $0.76 \pm 0.12$ \\
\hline
\end{tabular}

The spontaneous contractile activity of the stomach of $H$. malabaricus observed in the present experiment showed variable tension and constant frequency, confirming previous experiments (Baldisserotto et al., 1990). Spontaneous peristalsis was also described in the isolated gut of Salmo trutta (Burnstock, 1958a, b), in the stomach of Scorpaena sp. (Gzgzyan and Kuzina., 1973), and Pleuronectes platessa (Fänge and Grove, 1979). 


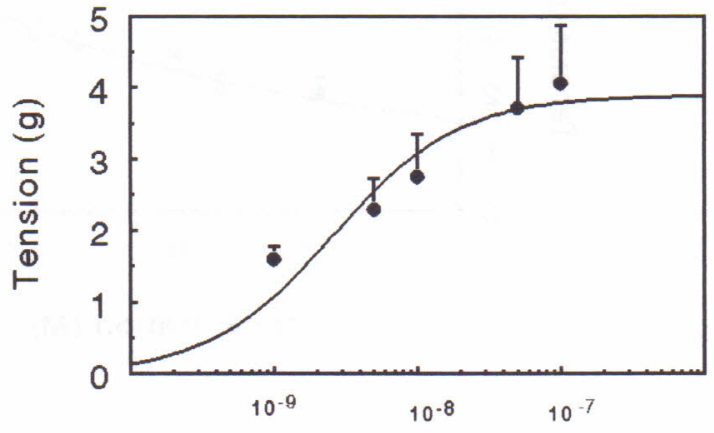

Concentration (M)

Figure 1 - Effect of acetylcholine on tension of gastric contractions of the stomach of Hoplias malabaricus. The following equation was fitted to the data:

$y=3.89 \times\left(2.637 \times 10^{-9}+x\right)^{-1} \quad r^{2}=0.96$

where $\mathrm{y}=$ tension $(\mathrm{g})$ and $X=$ concentration of acetylcholine

The results with acetylcholine and pilocarpine allow to conclude that the stomach of $H$. malabaricus has muscarinic receptors. Acetylcholine also caused contractions in the stomach of $\boldsymbol{A}$. anguilla (Nilsson and Fänge, 1967), and in the stomach and intestine of Gadus morhua (Nilsson and Fänge, 1969; Jensen and Holmgren, 1985). The stomach of $S$. gairdneri also contracts in the presence of this drug, but the contractile response declined in spite of its continued presence in the organ bath (Kitazawa et al., 1986), as observed in the stomach of $H$. malabaricus. These results indicate that acetylcholine is rapidly metabolized in these preparations. 


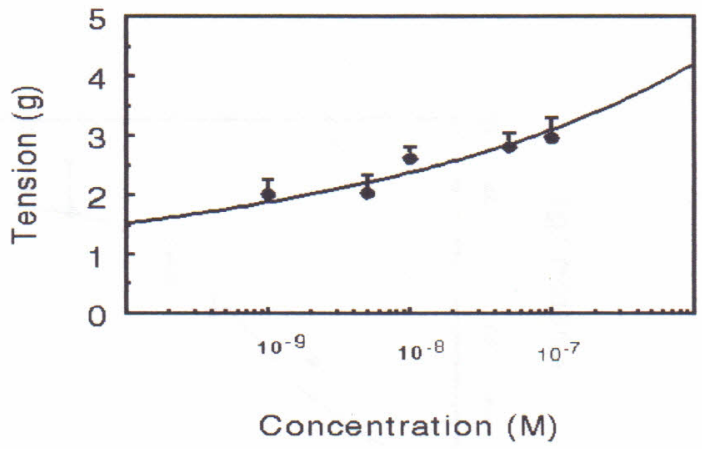

Figure 2 - Effect of pilocarpine on tension of gastric contractions of the stomach of Hoplias malabaricus. The following equation was fitted to the data: $y^{0.5}=0.0095-28.197 / 1 n(x) \quad r^{2}=0.99$ where $y=$ tension $(g)$ and $X=$ concentration of pilocarpine

The existence of adrenergic and serotonergic receptors in the stomach of $H$. malabaricus was not confirmed since these drugs did not alter the gastric contractions at the doses utilized. Adrenaline and acetylcholine have been reported to have antagonistic effects on the alimentary tract of fishes. Acetylcholine increased gastric motility in Lophius piscatorius while adrenaline caused relaxation of smooth muscle (Dreyer, 1949). The same occurs in the esophagus and intestine of Anguilla anguilla (Nilsson and Fange, 1967). However, Burnstock (1958a) observed that in the stomach of S. trutta these drugs are synergistic and induce contractions. Nilsson e Fänge (1967) found that the contractions of the stomach of Anguilla anguilla were stimulated by acetylcholine, adrenaline, noradrenaline, tyramine, and 
isoprenaline. Noradrenaline and adrenaline can also cause contraction of smooth muscle through the activation of $\alpha_{2}$ adrenoceptors in Salmo gairdneri. The contractile response to noradrenaline and adrenaline in this species involves both a direct action on smooth muscle and an indirect action through a non-cholinergic excitatory nerve (Kitazawa, 1986). Enteric neurons may release acetylcholine, 5-hydroxytryptamine and neuropeptides in various combinations (Holmgren and Nilsson, 1991; Jensen and Holmgren, 1993). However, acetylcholine and adrenaline might coexist in autonomic neurons innervating the spleen of the $\operatorname{cod} G$. morhua. This suggests an interesting evolutionary stage, in parallel with what is often seen in developing nerve cells in culture (Holmgren and Nilsson, 1976; Winberg et al., 1981). Serotonergic neurons occur in the gut of various species such as Chimaera monstrosa (Yui et al., 1990), Lepisosteus platyrhinchus (Holmgren and Nilsson, 1983b), Amia calva (Rajjo et al., 1989), Lepidosiren paradoxa, and Protopterus annectens (Nilsson and Holmgren, 1992). In catfish intestine serotonin produced contractile responses in a dose-dependent manner (Venugopalan et Al., 1995).

The present results allow us to conclude that the stomach of $H$. malabaricus has muscarinic receptors, but since adrenaline and serotonin did not alter the gastric contractions, the existence of adrenergic and serotonergic receptors in this species was not confirmed.

\section{ACKNOWLEDGMENTS}

The authors thank Mr. Florindo Duarte (UFSM) for technical assistance with fish collection, and Professor Baltazar Schirmer (UFSM) for a critical reading of this article. 


\section{REFERENCES}

Azevedo, P. de and Gomes, A.L. 1943. Contribuição ao estudo da biologia da traíra, Hoplias malabaricus (Bloch, 1794). Bol. Indust. Anim. São Paulo, 5(4): 15-64.

Baldisserotto, B; Mimura, O.M.; Farias, A.P.T; Christensen, F. 1990. Effect of luminal $\mathrm{pH}$ on gastric motility "in vitro" of Hoplias malabaricus (TELEOSTEI). Bol. Fisiol. Anim. S. Paulo, 14: 13-18.

Burnstock, G.1958a. The effects of drugs on spontaneous motility and response to stimulation of the extrinsic nerves of the gut of a teleostean fish. Br. J. Pharmacol., 13: 216-26.

Burnstock, G.1958b. Reversible inactivation of nervous activity of fish. J. Physiol. (London), 141: 35-45.

Dreyer, N. B. 1949. The action of autonomic drugs in elasmobranch and teleost involuntary muscle. Arch. Int. Pharmacodyn. Ther., 78: 63-66.

Edwards, D. J. 1972. Reactions of the isolated plaice stomach to applied drugs. Comp. Gen. Pharmacop., 3: 345-58.

Fänge, R. and Grove, D. J. 1979. Digestion. in: Fish Physiology (Ed. Hoar, W. S. \& Randall, D.J.), Vol. VIII - Bioenergetics and Growth, Academic Press, New York. pp. 161-260.

Grove, D. J. and Campbell, G. 1979. The role of extrinsic and intrinsic nerves in the coordination of gut motility in the stomachless flatfish Rhombosolea tapirina and Ammotretis rostrata Guenther. Comp. Biochem. Physiol., 63C: $143-59$.

Gzgzyan, D.M. and Kuzina, M.M. 1973. Stomach motor activity in the black sea ray Dasyatis pastinaca. J.Evol. Biochem. Physiol. (USSR), 9(5): 53638.

Holmgren, S. 1983. The effects of putative non-adrenergic, non- cholinergic autonomic transmitters on isolated strips from the stomach of the rainbow trout, Salmo gairdneri. Comp. Biochem. Physiol., 74C: 229-38.

Holmgren, S. and Jönson, A.C. 1988 Occurence and effects on motility of bombesin-related peptides in the gastrointestinal tract of the atlantic cod Gadus morhua. Comp. Biochem Physiol., 89C: 239-49.

Holmgren, S. and Nilsson, S. 1974. Drug effects on isolated artery strips from two teleosts, Gadus morhua and Salmo gairdneri. Acta Physiol. Scand., 90: 431-7.

Holmgren, S. and Nilsson, S. 1976. Effects of denervation , 6hydroxydopamine and reserpine on the cholinergic and adrenergic responses of the spleen of the cod, Gadus morhua. Eur. J. Pharmacol., 39: 53-58.

Holmgren, S. and Nilsson, S. 1983b. VIP, bombesin and neurotensin - like immunoreactivity in neurons of the gut of the holostean fish, Lepisosteus platyrhincus, Acta Zool. (Stockholm)., 64: 25-40. 
Holmgren, S. and Nilsson, S. 1991 Novel neurotransmiters in the autonomic nervous systems of non-mammalian vertebrates, in : Novel neurotransmitters sect. 135 of Int. Enciclo. Pharmacol. Ther, Bell, C. Series Ed. Pergamon Press, New York, pp. 293-300.

Jensen, J. and Holmgren, S. 1985. Neurotransmitters in the intestine of the atlantic cod, Gadus morhua. Comp. Biochem. Physiol., 82C (1): 81-90.

Jensen, J. and Holmgren, S. 1993. Gastrointestinal canal in: Comparative Physiology and Evolution of the Autonomic Nervous Sistem, series Ed. Harwood Academic Chur.

Jobling, M. (1995). Digestion and absorption in : Environmental Biology of Fishes. (ed. Chapman \& Hall).Great Britain. pp. 175-249.

Kitazawa, T.; Kondo, H.; Temma, K. 1986. $\alpha-2$ adrenoceptor-mediated contractile response to catecholaminas in smooth muscle strips isolated from rainbow trout stomach (Salmo gairdneri). Br. J. Pharmacol., 89(2): 259-266.

Menin, E. 1988. Anátomo-histologia funcional comparativa do aparelho digestivo de seis teleostei (PISCES) de água doce. Tese de doutoramento, IBUSP, Universidade de São Paulo, $380 \mathrm{p}$.

Mimura, O.M. and Baldisserotto, B. 1988. Plasma ionic and osmotic concentrations of two freshwater teleosts, Prochilodus affinis and Prochilodus marggravii in different gonadal stages. Bol. Fisiol. Anim. S. Paulo, 12: 21-30.

Nilsson, S. 1983. Autonomic Nerve Function in the Vertebrates. Springer, Berlin, 13: 121-145.

Nilsson, S. and Fänge, R. 1967. Adrenergic receptors in the swimbladder and gut of a teleost (Anguilla anguilla). Comp. Biochem. Physiol., 23: 661-64.

Nilsson, S. and Fänge, R. 1969. Adrenergic and cholinergic vagal effects on the stomach of a teleost (Gadus morhua). Comp. Biochem. Physiol., 30: 691-94.

Nilsson, S. and Holmgren, S. 1992. Autonomic nerve function and cardiovascular control in lungfish, in: Physiological adaptations in vertebrates. (Eds. Wood, S.C.; Webwe, R.E.; Hargens, A.R. and Millard, R.W.). Marcel Dekker, Inc. New York. pp 377-380.

Nilsson, S. and Holmgren, S. 1993. Autonomic nerve functions in: Physiology of fishes/ by David Evans. (CRC press, Inc). 10 pp. 279-303.

Rajjo, I.M.; Vigna, S.R. and Crim, J.W. 1989. Immunohistochemical localization of vasoactive intestinal polypeptide in the digestive tracts of a holostean and a teleostean fish. Comp. Biochem. Physiol., 94 C: 411 415.

Thorndyke, M. and Holmgren, S. 1990 Bombesin potentiates the effect of acethylcoline on isolated strips of fish stomach, Regul. Pept., 30: 125-135.

Venugopalan, C.S.; Holmes, E.P. \& Kleinow, K.M. 1995 Evidence for serotonin involvement in the NANC excitatory neurotransmission in the catfish intestine. J. Auton. Pharmacol., 15: 37-48. 
Winberg, M.; Holmgren, S. and Nilsson, S. 1981. effects of denervation and 6-hydroxydopamine on the action of choline acetyltransferase in the spleen of the cod Gadus morhua. Comp. Biochem. Physiol., 69 C: 141146.

Yui, R.; shimada, M.and Fujita, J. (1990). Immunohistochemical studies of peptide -and amine containing endocrine cells and nerves in the gut and the rectal gland of the rattifsh Chimaera monstrosa. Cell Tissue Res., 260: 193-198. 